\title{
İlköğretim Matematik Öğretmen Adaylarının Akademik Başarı ve Matematiğe Yönelik Tutumlarının Öğrenme Stilleri Açısından İncelenmesi*
}

\author{
H. Coşkun ÇELIK ${ }^{1}$, Samet GÜNDÜZ ${ }^{2}$ \\ ${ }^{1}$ Yrd. Dos. Dr., Sïrt Üniversitesi, Ë̆itim Fakültesi, Illkögretim Bölïmü, bcoskun.celik@gmail.com \\ 2 Öğretmen, MEB, Sarrca Ortaokulu, Eğil, Diyarbakır, asametgunduz@gmail.com
}

Bu çalışmanın amacı ilköğretim matematik öğretmen adaylarının akademik başarı ve matematiğe yönelik tutumlarını, öğrenme stilleri açısından incelemektir. Araştırmanın çalışma grubunu 2013-2014 akademik yllı bahar döneminde Siirt Üniversitesi Eğitim Fakültesi'nde ögrenim gören ilköğretim matematik öğretmen adayları oluşturmaktadır. Veri toplama aracı olarak Kişisel Bilgi Formu, Celik \& Bindak (2005) tarafından geliştirilen Matematiğe Yönelik Tutum Ölçeği ve Kolb (1999) tarafından geliștirilip Gencel (2007) tarafından Türkçeye uyarlanan Kolb Öğrenme Stilleri Envanteri 3.1 kullanılmıştır. Verilerin çözümlenmesinde frekans, yüzde, aritmetik ortalama, ki-kare testi, tek yönlü ANOVA testi ve korelasyon analizi kullanılmıştır. Araştırma sonuçlarına göre ilköğretim matematik öğretmen adaylarının ağırlıklı olarak değiștiren ve özümseyen öğrenme stillerini tercih ettikleri, matematiğe yönelik tutumlarının yüksek düzeyde olduğu, öğrenme stilleri ile cinsiyet, öğretim türü, akademik başarı ve matematiğe yönelik tutumlar arasındaki farkın ise istatistiksel olarak anlamlı olmadığı bulunmuştur.

Anahtar Kelimeler: öğrenme stilleri, akademik başarı, matematik, tutum

\section{Evaluation of Academic Achievement and Attitude Toward Mathematics in Terms of Learning Styles of Primary Mathematics Teacher Candidates}

\begin{abstract}
The aim of this study is to evaluate academic achievement and attitudes toward mathematics in terms of elementary mathematics teacher candidates learning styles. The study group consist of elementary mathematics teacher candidates studying in Siirt University Faculty of Education spring semester 2013-2014 academic year. As data collection tool, Personal Information Form, Attitude Toward Mathematics Scale which developed by Çelik \& Bindak (2005), Kolb Learning Style Inventory which developed by Kolb (1999) and adopted into Turkish by Gencel (2007) were used. Data were analyzed through frequency, percentage, mean, chi-square test, one way ANOVA and correlation analysis. According to research results; elementary mathematics teacher candidates prefer mostly learning styles which diverger and assimilation. Also their attitude toward mathematics is quite high. Finally, no significant differences were found between the learning styles with gender, type of education, academic achievement and attitudes toward mathematics.
\end{abstract}

Keywords: learning styles, academic achievement, mathematics, attitude

\section{GİRİ̧̧}

İnsan yaşamında çok önemli rolü olan öğrenme, eski çă̆lardan beri filozof ve bilim adamlarının farklı biçimlerde tanımladıkları ve açıklamaya çalıştıkları bir kavramdır (Aktaş \& Mirzeoğlu, 2009). Birçok kuramcı öğrenmenin değişik tanımlarını yapmıştır. Öğrenme için yapılan tanımlamaların ortak özelliği ise öğrenmeyi;

* Bu çalıs̆ma Bilimin Işı̆̆ında Eğitimsel Liderlik Üzerine Uluslararası Konferans, 22-24 Mayıs 2014, Sïrt'te bildiri olarak sunulmustur. 
yaşantı ürünü, kalıcı izli davranış değişikliği olarak tanımlamış olmalarıdır (Erol, 2013). Öğrenmenin bir yaşantı ürünü olması, öğrenenlerin bireysel olarak farklı olduklarını göstermektedir. Bu bireysel farklılıklarda öğrenmelerin farklılaşmasını beraberinde getirmektedir. Bireyler öğrenmede farklı yolları, yani öğrenme stillerini tercih edebilirler.

Öğrenme sürecinde her insanın öncelik verdiği birtakım yol ve yöntemler bulunmaktadır (Bahar, Özen \& Gülaçt1, 2009). Öğrenenin etkili bir şekilde öğrenebilmesi için kendini ve öğrenme yollarını tanıması gerekmektedir. Bireyler arasındaki farklılıkları inceleme sonucunda ise öğrenme stili kavramı ortaya çıkmıştır. Lemire'nin (1996) aktardığına göre; Keefe, öğrenme stili araştırmalarının 1892'de ortaya çıktığını ifade etmektedir. Keefe'ye (1979) göre öğrenme stili öğrencilerin nasıl algıladıklarını, etkileşime girdiklerini ve öğrenme ortamından nasıl etkilendiklerini gösteren bilişsel, duyuşsal ve fizyolojik özelliklerin karakteristik bir bileşimi iken (Akt. Önder, 2012), Felder ve Silverman'a (1988) göre bireylerin bilgiyi alma, tutma ve işleme sürecindeki karakteristik güçlülük ve tercihleridir (Akt. Veznedaroğlu \& Özgür, 2005). Alan yazın incelendiğinde öğrenme stilleri ile ilgili yapılan tanımlamaların çoğunluğunun ortak noktasının tüm bireylerin öğrenebileceği, ancak öğrenme şekillerinin birbirinden farklı olduğu ilkesini temel almış oldukları görülmektedir (Açık, 2013). Öğrenme stilleri son yüzyılda birçok araştırmaya konu olsa da araştırmacılar tarafindan üzerinde fikir birliğine varılmış tek bir öğrenme stili modeli bulunmamaktadır (Önder, 2012). Son 60 yıldır öğrenme stilleri üzerinde yapılan araştırmalar sonucunda bugüne kadar pek çok öğrenme stili modeli tanımlanmıştır (Peker \& Aydın, 2003). Bu araştırmada da kullanılan Kolb Öğrenme Stili Modeli de bunlardan biridir. David A. Kolb alanyazında öğrenme stilleri hakkında en fazla çalışması olan araştırmacılar arasındadır (Açı, 2013). Ayrıca öğrenme stilleri ile ilgili yerli ve yabancı alanyazın incelendiğinde Kolb’un Yaşantısal Öğrenme Kuramına uygun olarak geliştirdiği öğrenme stili envanteri yurt içi ve yurt dışında yapılan çalışmalarda yaygın bir şekilde kullanılmaktadır.

Kolb’a göre bireyler kendi yaşantıları ve deneyimleri sayesinde öğrenirler ve bu öğrenmenin sonuçları güvenli bir şekilde değerlendirilebilir. Yaşantısal öğrenme, kişisel gelişim ve öğrenme için seçim metodu olmuş, yaşantıya dayalı eğitim, kolej ve üniversitelerde yaygın şekilde bir öğretim metodu olarak kabul edilir hale gelmiştir. Yaşantısal öğrenme kuramının, öğrenme sürecine yaklaşımı davranışçı ve bilişsel alan öğrenme süreçlerinden farklıdır (Şirin \& Güzel, 2006). Kolb (1984) Yaşantısal öğrenme kuramına göre öğrenmeyi dört aşamalı bir döngü olarak tasarlamıştır. Bu döngü içerisinde dört öğrenme biçimi bulunmaktadır. Bunlar somut yaşantı (SY), yansıtıcı gözlem (YG), soyut kavramsallaştırma (SK) ve aktif yaşantıdır (AY). Kolb’a göre öğrenme sürecinin iki temel boyutu vardır. Bunlardan birincisi; soyut kavramsallaştırmadan somut yaşantıya uzanır, ikincisi; aktif yaşantıdan yansıtıcı gözleme uzanır. Kolb öğrenme stili modelinde SY ve SK, bireyin bilgiyi nasıl algıladığını, YG ve AY bireyin bilgiyi nasıl işlediğini açıklar. Her bir öğrenme biçimini simgeleyen öğrenme yollarındaki tercihleri birbirinden farklıdır. Bunlar sırasıyla SY için "hissederek", YG için "izleyerek”, SK için “düşünerek" ve AY için "yaparak” öğrenmedir. Yani, Kolb öğrenme stili modeline göre bireyler bilgiyi hissederek veya düşünerek algilar, izleyerek veya yaparak işlerler. (Akt. Karademir \& Tezel, 2010).

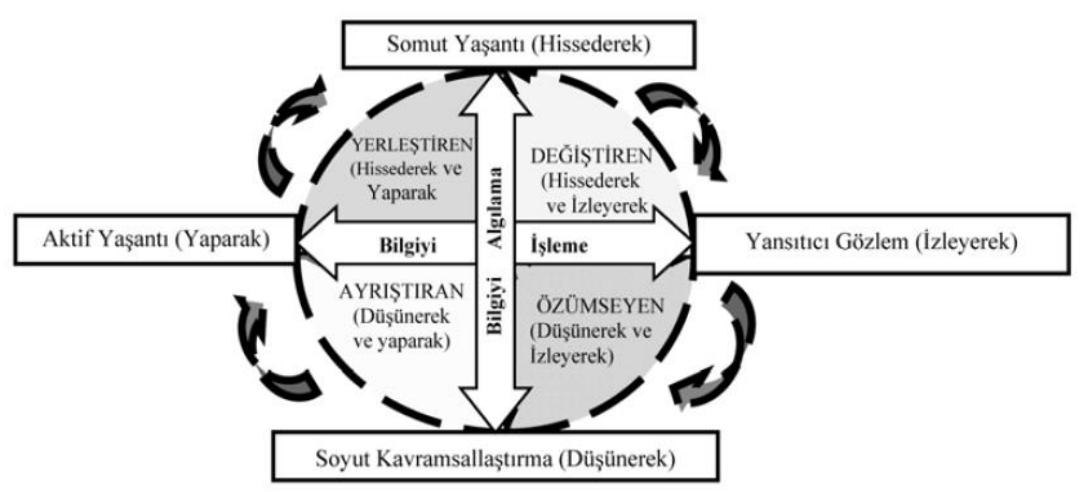

Şekil 1. Kolb Öğrenme Modeline Göre Öğrenme Çemberi (Aktaş \& Mirzeoğlu, 2009) 
Kolb \& Kolb (2005), bireylerin öğrenme stilini tek bir yeteneğin belirlemediğini ve her bireyin öğrenme stilinin, dört öğrenme biçiminin bileşeni olduğunu belirtmiştir. Ayrıştıran, değiştiren, özümseyen ve yerleştiren olmak üzere dört temel öğrenme stili tespit eden Kolb \& Kolb (2005), bu öğrenme stillerine sahip olan bireylerin özelliklerini kısaca şöyle açıklamıştır: Değiş̧iren (Diverger) öğrenme stiline sahip bireylerin somut yaşantı ve yansıtıcı gözlem yetenekleri daha baskındır. Bu öğrenme stiline sahip bireylerin kültürel ilgileri yoğundur ve bu bireyler fikir üretiminin gerektiği durumlarda daha iyi performans sergilerler. Değiştirenler yaratıcı ve duygusal olma eğilimindedirler ve sanatta uzmanlaşabilirler. Özümseyen (Assimilation) öğrenme stiline sahip bireylerin soyut kavramsallaştırma ve yansıtıcı gözlem yetenekleri daha baskındır. Bu öğrenme stiline sahip bireyler insanlara daha az odaklanarak, fikirler ve soyut kavramlarla daha fazla ilgilenirler ve genellikle teorilerin mantıksal sağlamlı̆̆ını, pratik değerlerinden daha önemli bulurlar. Ayrıştıran (Converger) öğrenme stiline sahip bireylerin soyut kavramsallaştırma ve somut yaşantı yetenekleri daha baskındır. Bu öğrenme stiline sahip insanlar fikir ve teoriler için pratik kullanımlar bulmada başarılıdır. Problem çözme, soru veya sorunlara çözüm bulma ve karar alma konusunda yeteneklidirler. Ayrıştıranlar, sosyal konular ve kişiler arası problemlerle başa çıkmak için teknik görevleri tercih ederler. Yerleştiren (Accommodation) öğrenme stiline sahip bireylerin somut yaşantı ve aktif yaşantı yetenekleri daha baskındır. Bu öğrenme stiline sahip insanlar öncellikle deneyip uygulayarak öğrenme yeteneğine sahiptir. Planlama yapmaktan, zorlu ve yeni deneyimlerden hoşlanırlar. Mantıksal analizler üzerinde hareket etmekten ziyade daha çok hisleri ile hareket etme eğilimindedirler. Yerleştiren öğrenme stiline sahip bireyler sorunların çözümünde kendi teknik analizlerine daha fazla güvenirler.

Literatürde öğrenme stilleri ile ilgili yapılan çalışmalar incelendiğinde dikkat çekici sonuçlara ulaşıldığı görülmüştür. Ülkemizde ve yurt dışında, Kolb Öğrenme Stilleri Envanteri kullanılarak yapılan çalışmaların çoğunun deneysel veya ilişkisel çalışmalar olduğu, betimsel çalışmaların ise daha az sayıda olduğu görülmektedir. Yapılan ilişkisel çalışmalarda genellikle öğrenme stilleri ile yaş, cinsiyet, bölüm gibi çeşitli değişkenler arasındaki ilişki araştırılırken, deneysel çalışmalarda daha çok öğrenme stillerinin akademik başarı, hatırda tutma düzeyi gibi değişkenlere etkisinin olup olmadığına bakılmıştır. Betimsel çalışmalarda ise genellikle öğrenme stillerinin bazı değişkenlere göre değişip değişmediği incelenmiştir. Yapılan çalışmalardan, Çelik, Yalçın, Çatal \& Aydın (2014) tarafindan öğretmen adaylarının öğrenme stillerinin bazı değişkenlere göre incelenmesi amacıyla yapılan çalışmada ilköğretim matematik öğretmen adaylarının baskın olarak özümseyen öğrenme stiline sahip olduğu sonucuna ulaşmıştır. Bahar, Özen \& Gülaçtı (2009) ise öğretmen adaylarının cinsiyet ve branşa göre akademik başarı durumları ile öğrenme stillerini incelemiş, ilköğretim matematik öğretmen adaylarının baskın olarak ayrıştıran öğrenme stiline sahip olduğunu, akademik başarı düzeyleri ve cinsiyet ile öğrenme stilleri arasında istatistiksel olarak anlamlı bir ilişkinin olmadığı sonucuna ulaşmıştır. Diğer bir araştırmada ise Küçükkaragöz, Deniş, Ersoy \& Karataş (2012), ilköğretim matematik, fen bilgisi ve türkçe öğretmen adaylarının öğrenme stilleri ve problem çözme becerilerini incelemiş ve ilköğretim matematik öğretmen adaylarının çoğunluğunun ayrıştıran öğrenme stiline sahip olduğu bulgusuna ulaşmıştır. Okur, Bahar, Akgün \& Bekdemir (2011) de "Matematik Bölümü Öğrencilerinin Öğrenme Stilleri ile Sürekli Kayg1 ve Akademik Başarı Durumları” başlıklı çalışmalarında ilköğretim matematik öğretmen adayları ve matematik bölümü öğrencileri üzerinde çalışış ve ilköğretim matematik öğretmen adaylarının baskın olarak ayrıştıran ve özümseyen öğrenme stillerine sahip olduklarını ortaya koymuştur.

Günümüzde bireylerin öğrenme süreci üzerinde yoğunlaşan eğitim bilimciler öğrenme sürecini etkileyen çevre, yöntem, tutum, motivasyon, kişilik, yaş, yetenek, hafiza, ve alg1 gibi çeşitli iç ve dış faktörler üzerinde araştırmalar yapmaktadırlar (Can, 2011). Hein \& Budny de (2000) bireylerin öğrenme stilini değerlendirmenin, öğretme ve öğrenme süreci için çok önemli olduğunu belirtmiştir. Çakır \& Akbaş'a (2013) göre bireyin öğrenme stilinin bilinmesi, öğrenme-öğretme süreçlerinin tasarlanmasından, kullanılacak öğretim materyallerine ve değerlendirme şekillerine kadar birçok boyuta önemli katkılar sağlamaktadır. Öte yandan öğrenme stillerine etki eden değişkenlerin belirlenmesi ile bu değişkenleri kontrol altına alma ya da 
yönlendirme mümkün olabilir. Öğrenme sürecini etkileyen değişkenlerden biri de tutumdur. Tutum, en genel anlamıyla "bireyi yönlendiren, bilişsel ve duyuşsal bileşenleri olan bir eğilim" olarak tanımlanabilir (Alkan, Güzel \& Elçi, 2004). Tutumun bireyi yönlendiren bir unsur olduğu göz önünde bulundurulduğunda, ilköğretim matematik öğretmen adaylarının matematiğe yönelik tutumlarının, öğrenme stillerini etkileyip etkilemediğinin bilinmesi yapılacak olan çalısmaların verimli olabilmesi için önem taşımaktadır. Literatürde ilköğretim matematik öğretmen adaylarının matematiğe yönelik tutumlarını, öğrenme stilleri açısından inceleyen herhangi bir çalışmaya rastlanmamıştır. Bu açıdan bakııldığında yapılan bu çalışmanın, öğretmen adaylarına, öğretim üyelerine ve literatüre katkı sağlayacağı düşünülmektedir.

Bütün bu açıklamalar ışığında; öğrenme stilleri ile ilgili çalışmaların önemli bir araştırma konusunu oluşturduğu görülmektedir. Bu araştırmada da öğretmen adaylarının öğrenme stillerinin akademik başarıları ve matematiğe yönelik tutumları açısından incelemek amaçlanmış ve bu amaç doğrultusunda aşağıdaki sorulara yanıt aranmıştır:

Araştırma kapsamına alınan öğretmen adaylarının;

Baskın öğrenme stilleri nedir?

Öğrenme stilleri, cinsiyet, sınıf düzeyi ve öğretim türüne göre anlamlı farklılık göstermekte midir?

Öğrenme stilleri ile akademik başarıları arasında anlamlı bir farklılık var mıdır?

Öğrenme stilleri ile matematiğe yönelik tutumları arasında anlamlı bir farklılık var mıdır?

\section{YÖNTEM}

Araştırma var olan bir durumu betimlemek için tarama modelinde yapılmış betimsel bir çalışma olup bu bölümde, araştırmanın çalışma grubu, veri toplama araçları, veri toplama ve analiz işlemleri hakkında bilgi verilmektedir.

\section{1. Çalışma Grubu}

Araştırmanın çalışma evrenini 2013-2014 akademik yllı bahar dönemimde Siirt Üniversitesi Eğitim Fakültesi, İlköğretim Matematik Öğretmenliği programında öğrenim gören öğretmen adayları (3. ve 4. Sınıf) oluşturmaktadır. Örneklem alma yoluna gidilmeyip evrenin tamamına ulaşılmaya çalışılmıştır. Katılımcılar seçilirken belli düzeyde matematik tecrübesine sahip olmalarına dikkat edilmiştir. Ulaşılabilen 176 öğretmen adayı araştırmanın örneklemini oluşturmuştur. Ancak örnekleme uygulanan anketlerden hatalı ve eksik doldurulan 30 anket çıarıldıktan sonra, toplam 146 anket değerlendirmeye alınmıştır. Bu değer evrenin yaklaşık olarak \%61'ini temsil etmektedir. Araştırmaya katılan öğretmen adaylarının cinsiyetlerine, öğretim türlerine ve sınıf düzeylerine göre dağılımı Tablo 1'de verilmiştir.

Tablo 1. Araștırmaya katılan öğretmen adayları

\begin{tabular}{|c|c|c|}
\hline & f & $\%$ \\
\hline \multicolumn{3}{|l|}{ Cinsiyet } \\
\hline Bayan & 72 & 49,3 \\
\hline Erkek & 74 & 50,7 \\
\hline \multicolumn{3}{|l|}{ Sınıf Düzeyi } \\
\hline 3. Sinif & 66 & 45,2 \\
\hline 4. Sinif & 80 & 54,8 \\
\hline \multicolumn{3}{|l|}{ Öğretim Türü } \\
\hline Normal Öğretim & 102 & 69,9 \\
\hline İkinci Öğretim & 44 & 30,1 \\
\hline Toplam & 146 & 100 \\
\hline
\end{tabular}

Araştırmaya 72'si bayan, 74’ü erkek olmak üzere toplam 146 öğretmen adayı katılmıştır. Öğretmen adaylarından \%45,2'si 3. sınıf düzeyinde, $\% 54,8$ ’ i ise 4. sınıf düzeyinde yer almaktadır. Öğretmen adaylarının \%69,9’u normal öğretimde, \%30,1 ikinci öğretimde öğrenimlerini sürdürmektedirler. 


\subsection{Veri Toplama Araçları}

Araştırma verilerinin elde edilmesinde (a) Kişisel Bilgi Formu, (b) Kolb Öğrenme Stilleri Envanteri Versiyon III (KÖSE-III) ve (c) Matematik Tutum Ölçeği (MTÖ) kullanılmıştır.

a) Kişisel Bilgi Formu: Öğretmen adaylarının cinsiyet, öğretim türü, sınıf düzeyi ve akademik not ortalamaları olmak üzere dört adet sorudan oluşmaktadır.

b) KÖSE-III: Öğrenme stillerini belirlemek için Kolb (1999) tarafından geliştirilen ve Gencel (2007) tarafindan Türkçeye uyarlanan KÖSE-III kullanılmıştır. Envanter 12 adet eksik bırakılmış maddeden oluşmaktadır. Her bir maddede bulunan dört seçenek 1 ile 4 arasında puanlanmaktadır. Ölçekten alınan en düşük puan 12, en yüksek puan 48'dir. Bu puanlamadan sonra birleştirilmiş puanlar hesaplanmaktadır. Birleştirilmiş puanlar SK-SY ve AY-YG seklinde elde edilmekte ve bu işlem sonucunda alınan puanlar -36 ile +36 arasında değişmektedir. SK-SY ile elde edilen pozitif puan öğrenmenin soyut, negatif puan ise somut olduğunu; benzer şekilde, AY-YG ile elde edilen puanlar, öğrenmenin aktif ya da yansıtıcı olduğunu göstermektedir. Birleştirilmiş puanlardan AY-YG koordinat sistemi üzerinde x-eksenine, SK-SY y-eksenine yerleştirilmekte ve bu iki puanın kesiştiği alan bireyin öğrenme stilini göstermektedir (Gencel 2007).

Öğrenme biçimlerinden elde edilen puanların Cronbach alpha güvenirlik katsayıları Kolb (1999) tarafindan, Türkçeye uyarlanan envanter için ise Gencel (2007) tarafından hesaplanmıştır. Öğrenme biçimlerinden elde edilen puanların Cronbach alpha güvenirlik katsayıları Tablo 2'de verilmiştir.

Tablo 2. KÖSE-III Cronbach alpha güvenirlik katsayıları

\begin{tabular}{lccc}
\hline $\begin{array}{l}\text { Öğgrenme } \\
\text { Biçimleri }\end{array}$ & $\begin{array}{c}\text { Kolb 1999 } \\
\text { (f: 1052) }\end{array}$ & $\begin{array}{c}\text { Cronbach Alpha } \\
\text { Gencel 2007 } \\
\text { (f: 320) }\end{array}$ & $\begin{array}{c}\text { Mevcut Çalsşma } \\
\text { (f: 146) }\end{array}$ \\
\hline SY & .81 & .76 & .71 \\
YG & .73 & .71 & .68 \\
SK & .83 & .80 & .63 \\
AY & .78 & .75 & .60 \\
\hline
\end{tabular}

Yapılan hesaplamalar sonucunda öğrenme biçimlerinin Cronbach alpha güvenirlik değerlerinin 0.60 ile 0.71 arasında olduğu görülmektedir. Bu değerlerden hareketle envanterin kullanılması için yeterli güvenirlikte olduğu söylenebilir.

Uygulanan envanterin ortalama ve standart sapma değerleri Tablo $3^{\prime}$ te gösterilmiştir.

Tablo 3. KÖSE-III ortalama ve standart sapma değerleri

\begin{tabular}{lcc} 
Tablo 3. KÖE-III ortalama ve standart sapma değerleri & Ss \\
\hline Öğrenme Biçimleri & Ortalama & 4,51 \\
\hline SY & 29,31 & 4,01 \\
YG & 30,02 & 3,80 \\
SK & 29,14 & 5,43 \\
AY & 31,36 & 6,48 \\
SK-SY & $-0,17$ & 7,86 \\
AY-YG & 1,34 & \\
\hline
\end{tabular}

Öğrenme biçimlerinden alınabilecek en düşük puan 12, en yüksek puan 48'dir. Birleştirilmiş puanlar ise 36 ile +36 arasında değişmektedir. Tablo 3’te görüldüğü gibi, öğrenme biçimleri puanlarının ortalamaları 29,14 ile 31,36 arasında değişmektedir. Birleştirilmiş puanlarda ise, SK-SY için ortalama -0,17; AY-YG için ortalama 1,34 olarak hesaplanmıştır.

$\mathrm{Bu}$ çalışmadan elde edilen KÖSE ve bileşenlerine ait puanların korelasyon katsayıları Tablo 4'te gösterilmiştir. Tablo 4'e göre dört temel öğrenme stili arasındaki korelasyonların negatif yönde olduğu görülmektedir. SK-SY ile SY ve AY-YG ile YG arasında yüksek düzeyde negatif yönde ilişki varken, SK-SY ile SK ve AY-YG ile AY arasında yüksek düzeyde pozitif yönde ilişki vardır. 
Tablo 4. KÖSE-III'den elde edilen puanların pearson korelasyon katsayıları

\begin{tabular}{|c|c|c|c|c|c|c|}
\hline $\begin{array}{l}\text { Öğrenme } \\
\text { Biçimleri }\end{array}$ & SY & YG & SK & AY & SK-SY & AY-YG \\
\hline SY & 1 & $-0,212\left(^{*}\right)$ & $-0,210\left(^{*}\right)$ & $-0,504(* *)$ & $-0,819\left(^{* *}\right)$ & $-0,240(* *)$ \\
\hline YG & $-0,212(*)$ & 1 & $-0,163\left(^{*}\right)$ & $-0,372(* *)$ & 0,052 & $-0,767(* *)$ \\
\hline SK & $-0,210\left(^{*}\right)$ & $-0,0163\left(^{*}\right)$ & 1 & $-0,353(* *)$ & $0,733(* *)$ & $-0,161$ \\
\hline AY & $-0,504(* *)$ & $-0,372(* *)$ & $-0,353(* *)$ & 1 & 0,144 & $0,881(* *)$ \\
\hline SK-SY & $-0,819(* *)$ & 0,052 & $0,733(* *)$ & 0,144 & 1 & 0,073 \\
\hline AY-YG & $-0,240(* *)$ & $-0,767(* *)$ & $-0,161$ & $0,881(* *)$ & 0,073 & 1 \\
\hline
\end{tabular}

c) MTÖ: Araştırmada öğretmen adaylarının matematiğe yönelik tutumlarını ölçmek için Çelik \& Bindak (2005) tarafindan geliştirilen Matematik Tutum Ölçeği kullanılmıştır. 5’li likert tipindeki ölçeğin Cronbach alpha güvenirlik katsayısı Çelik \& Bindak (2005) tarafindan 0.88 olarak bulunmuştur. Bu çalışmadan elde edilen Cronbach alpha güvenirlik katsayısı da $0.88^{\prime}$ dir. Bu değerler ölçeğin yüksek derecede güvenilir olduğunu göstermektedir. Ölçek yarısı olumlu, yarısı olumsuz olmak üzere toplam 20 maddeden oluşmaktadır.

\subsection{Verilerin Toplanmas1}

Bu araştırmanın verileri 2013-2014 akademik yılı bahar döneminde Siirt Üniversitesi Eğitim Fakültesinde öğrenim gören ilköğretim matematik öğretmen adaylarına uygulanan Kişisel Bilgi Formu, KÖSE-III ve MTÖ ile elde edilmiştir. Verilerin toplanması işlemi grup halinde sınıf ortamında gerçekleştirilmiştir.

\subsection{Verilerin Çözümlenmesi}

Verilerin çözümlenmesinde SPSS 15.0 paket programı kullanılmıştır. Öğretmen adaylarının öğrenme stillerinin belirlenmesinde KÖSE normları dikkate alınmıştır. Öğrenme stilleri frekans ve yüzde tablosuyla gösterilmiştir. Öğrenme stillerinin, cinsiyet, sınıf düzeyi ve öğretim türüne göre farklllık gösterip göstermediğini belirlemek için ki-kare testi, akademik başarı durumları ve matematiğe yönelik tutumlarına göre farklılık gösterip göstermediğini belirlemek için ise tek yönlü ANOVA testi kullanılmıştır. Anlamlılık düzeyi 0.05 olarak alınmıştır. Ölçeklerin güvenirliği Cronbach alfa katsayısı ile sınanmıştır.

Aralık belirlemek için (5-1)/5= formülü kullanılmış ve 0,80 değeri bulunmuştur. Buna göre araştırmanın alt problemleri doğrultusunda verilen bulgular öğrenci tutum puanlarının hesaplanan ortalama değeri; 5,004,20 arasında ise ankette ifade edilen görüşlere "Tamamen Katılıyorum”, 4,19-3,40 arasında ise ankette ifade edilen görüşlere "Katıllyorum", 3,39-2,60 arasında ise ankette ifade edilen görüşlere "Kararsızım”, 2,59-1,80 arasında ise ankette ifade edilen görüşlere "Katılmıyorum", 1,79-1,00 arasında ise ankette ifade edilen görüşlere "Hiç Katılmıyorum” şeklinde ifade edilmiştir (Ateş, 2010).

\section{BULGULAR}

Araştırmanın amacı doğrultusunda cevabı aranan illk soru öğretmen adaylarının baskın öğrenme stillerinin nasıl olduğudur. Bu amaçla ilk olarak öğretmen adayların öğrenme stillerinin frekans ve yüzde değerleri belirlenerek Tablo 5 'te sunulmuștur.

Tablo 5. Öğretmen adaylarının baskın öğrenme stillerinin dağılımı

\begin{tabular}{lcc}
\hline Öğrenme Stilleri & f & \% \\
\hline Değiştiren & 45 & 30,8 \\
Yerleştiren & 27 & 18,5 \\
Ayristıran & 27 & 18,5 \\
Özümseyen & 47 & 32,2 \\
Toplam & $\mathbf{1 4 6}$ & $\mathbf{1 0 0}$ \\
\hline
\end{tabular}

Araştırmaya katılan tüm öğretmen adaylarının \%32,2'sinin özümseyen, \%30,8’inin değiştiren, \%18,5’inin yerleştiren ve \%18,5’inin ayrıştıran öğrenme stiline sahip olduğu bulgusuna ulaşılmıştır. Bu sonuçlar doğrultusunda araştırmaya katılan tüm öğretmen adaylarının ağırlıklı olarak özümseyen ve değiştiren öğrenme stilline sahip oldukları bulunmuştur. 
Öğretmen adaylarının öğrenme stillerinin cinsiyete göre anlamlı farklılık gösterip göstermediğini tespit etmek için ki-kare testi yapılmış ve sonuçlar Tablo 6'da gösterilmiştir.

Tablo 6. Cinsiyete göre öğrenme stillerine ilişkin ki-kare testi sonuçları

\begin{tabular}{|c|c|c|c|c|c|}
\hline \multirow{2}{*}{ Değişken } & Değiştiren & Yerleştiren & Ayrıştıran & Özümseyen & Toplam \\
\hline & $f(\%)$ & $f(\%)$ & $\mathrm{f}(\%)$ & $\mathrm{f}(\%)$ & $f(\%)$ \\
\hline Bayan & $19(\% 26,4)$ & $16(\% 22,2)$ & $18(\% 25)$ & $19(\% 26,4)$ & $72(\% 100$ \\
\hline Erkek & $26(\% 35,1)$ & $11(\% 14,9)$ & $9(\% 12,2)$ & $28(\% 37,8)$ & $74(\% 100)$ \\
\hline Toplam & $45(\% 30,8)$ & $27(\% 18,5)$ & $27(\% 18,5)$ & $47(\% 32,2)$ & $146(\% 100)$ \\
\hline
\end{tabular}

$\chi^{2}=6,712, \mathrm{df}=3, \mathrm{p}=0.082$

Cinsiyete göre öğretmen adaylarının öğrenme stillerine ilişkin ki-kare testi sonuçları Tablo 6'da gösterilmiştir. Araştırmaya katılan bayan öğretmen adaylarının baskın olarak değiştiren ve özümseyen öğrenme stillerine eşit oranda $(\% 26,4)$ sahip olduğu, erkek öğretmen adaylarının ise baskın olarak özümseyen $(\% 37,8)$ öğrenme stiline sahip olduğu tespit edilmiştir. Yapılan ki-kare testi sonuçlarına göre öğretmen adaylarının öğrenme stillerinde cinsiyetlerine göre gözlenen farkın anlamlı olmadığı bulunmuştur $\left(\chi^{2}=6,712 ; p>0,05\right)$.

Öğretmen adaylarının öğrenme stillerinin öğretim türüne göre anlamlı farklılık gösterip göstermediğini tespit etmek için ki-kare testi yapılmış ve sonuçlar Tablo 7'de gösterilmiştir.

Tablo 7. Öğretim türüne göre öğrenme stillerine ilişkin ki-kare testi sonuçları

\begin{tabular}{|c|c|c|c|c|c|}
\hline \multirow{2}{*}{ Değişken } & Değiştiren & Yerleştiren & Ayriştıran & Özümseyen & Toplam \\
\hline & $f(\%)$ & f $(\%)$ & $f(\%)$ & f $(\%)$ & $f(\%)$ \\
\hline Normal Öğretim & $35(\% 34,3)$ & $16(\% 15,7)$ & $22(\% 21,7)$ & $29(\% 28,3)$ & $102(\% 100)$ \\
\hline İkinci Öğretim & $10(\% 22,7)$ & $11(\% 25)$ & $5(\% 11,4)$ & $18(\% 40,9)$ & $44(\% 100)$ \\
\hline Toplam & $45(\% 30,8)$ & $27(\% 18,5)$ & $27(\% 18,5)$ & $47(\% 32,2)$ & $146(\% 100)$ \\
\hline
\end{tabular}

$\chi^{2}=5,999, \mathrm{df}=3, \mathrm{p}=0,112$

Öğretim türüne göre öğretmen adaylarının öğrenme stillerine ilişkin ki-kare testi sonuçları Tablo 7'de gösterilmiştir. Tabloya göre normal öğretimde öğrenim gören öğretmen adaylarının baskın olarak değiştiren (\%34,3), ikinci öğretimde öğrenim gören öğretmen adaylarının ise baskın olarak özümseyen $(\% 40,9)$ ögrenme stiline sahip oldukları görülmektedir. Yapılan ki-kare testi sonuçlarına göre öğretmen adaylarının öğrenme stillerinde öğretim türüne göre gözlenen farkın anlamlı olmadığı bulunmuştur $\left(\chi^{2}=5,999 ; \mathrm{p}>0,05\right)$.

Öğretmen adaylarının öğrenme stillerinin sınıf düzeyine göre anlamlı farklılık gösterip göstermediğini tespit etmek için Ki-kare testi yapılmış ve sonuçlar Tablo 8'de gösterilmiştir.

Tablo 8. Sınıf düzeyine göre öğrenme stillerine ilișkin ki-kare testi sonuçları

\begin{tabular}{|c|c|c|c|c|c|}
\hline \multirow{2}{*}{ Değişken } & Değiştiren & Yerleştiren & Ayriştıran & Özümseyen & Toplam \\
\hline & $f(\%)$ & $f(\%)$ & $\mathrm{f}(\%)$ & $f(\%)$ & $f(\%)$ \\
\hline 3. Sinif & $17(\% 25,8)$ & $15(\% 22,7)$ & $15(\% 22,7)$ & $19(\% 28,8)$ & $66(\% 100)$ \\
\hline 4. Sinif & $28(\% 35)$ & $12(\% 15)$ & $12(\% 15)$ & $28(\% 35)$ & $80(\% 100)$ \\
\hline Toplam & $45(\% 30,8)$ & $27(\% 18,5)$ & $27(\% 18,5)$ & $47(\% 32,2)$ & $146(\% 100)$ \\
\hline
\end{tabular}

$\chi^{2}=3,771, \mathrm{df}=3, \mathrm{p}=0,287$

Sınıf düzeyine göre öğretmen adaylarının öğrenme stillerine ilişkin ki-kare testi sonuçları Tablo 8'de gösterilmiştir. Tabloya göre 3. sınıfta öğrenim gören öğretmen adaylanının baskın olarak özümseyen (\%28,8), 4. sınıfta öğrenim gören öğretmen adaylarının ise baskın olarak özümseyen ve değiştiren öğrenme stiline eşit oranda (\%35) sahip oldukları görülmektedir. Yapılan ki-kare testi sonuçlarına göre öğretmen adaylarının öğrenme stillerinde öğretim türüne göre gözlenen farkın anlamlı olmadığı bulunmuştur $\left(\chi^{2}=3.71 ; p>0,05\right)$.

Öğretmen adaylarının öğrenme stillerine göre akademik not ortalamaları ve standart sapma değerleri Tablo 9'da verilmiştir. 
Tablo 9. Öğrenme stillerine göre akademik not ortalamaları, standart sapma değerleri

\begin{tabular}{lccc}
\hline Öğrenme Stili & $\mathbf{f}$ & $\begin{array}{c}\text { Akademik Not } \\
\text { Ortalamasi }\end{array}$ & Ss \\
\hline Değiştiren & 45 & 70,33 & 5,568 \\
Yerleştiren & 27 & 71,22 & 4,774 \\
Ayriştıran & 27 & 70,48 & 4,734 \\
Özümseyen & 47 & 69,45 & 4,206 \\
Toplam/Ortalama & $\mathbf{1 4 6}$ & $\mathbf{7 0 , 2 4}$ & $\mathbf{4 , 8 5 0}$ \\
\hline
\end{tabular}

Tablo 9'a göre yerleştiren öğrenme stilindeki öğretmen adayları en yüksek not ortalamasına $(71,22)$ sahipken en düşük not ortalamasına $(69,45)$ ise özümseyen öğrenme stilindeki öğretmen adayları sahiptir. Bu sonucun anlamlı olup olmadığını tespit etmek için tek yönlü ANOVA testi yapılmış ve sonuçlar Tablo 10'da sunulmuştur.

Tablo 10. Öğrenme stillerine göre akademik not ortalamaları ilişkin ANOVA testi

\begin{tabular}{lccccc}
\hline & $\begin{array}{c}\text { Kareler } \\
\text { Toplami }\end{array}$ & Df & Ortalama Kare & f & Anlaml11k \\
\hline Gruplar Aras1 & 57,585 & 3 & 19,195 & \\
Grup İçi & 3353,024 & 142 & 23,613 & 0,813 & 0,489 \\
Toplam & $\mathbf{3 4 1 0 , 6 1 0}$ & $\mathbf{1 4 5}$ & & &
\end{tabular}

Tablo 10'daki öğretmen adaylarının öğrenme stillerine göre akademik not ortalamalarına ilişkin yapılan tek yönlü ANOVA testi sonuçlarına göre aradaki farkın anlamlı olmadığı bulunmuştur $(p=0,489 ; p>0,05)$.

Araştırma kapsamına alınan öğretmen adaylarının MTÖ'den aldığı puanların genel dağılımı Tablo 11'de verilmiştir.

Tablo 11. MTÖ'den alınan puanlarının genel dağılımı

\begin{tabular}{lcccc}
\hline & $\mathbf{n}$ & Ortalama & Ss & Min-Mak \\
\hline MTÖ puan ortalaması & 146 & 4,085 & 0,634 & $1,70-5,00$ \\
\hline
\end{tabular}

Tablo 11 incelendiğinde genel MTÖ puan ortalamasının 4,085 ve standart sapmasının 0,634 olduğu görülmektedir. Bu değer MTÖ’de "Katılıyorum” seçeneğine denk gelmektedir. Bu bulgu araştırma kapsamına alınan öğretmen adaylarının matematiğe yönelik tutumlarının yüksek düzeyde olduğunun göstergesidir.

Öğretmen adaylarının öğrenme stillerine göre MTÖ puanlarının ortalaması ve standart sapma değerleri Tablo 12'de verilmiştir. Buna göre özümseyen öğrenme stilindeki öğretmen adayları en yüksek tutum puan ortalamasına $(4,166)$ sahipken en düşük tutum puan ortalamasına $(3,961)$ ise yerleştiren öğrenme stilindeki öğretmen adayları sahiptir.

Tablo 12. Öğrenme stillerine göre MTÖ puanları ve standart sapma değerleri

\begin{tabular}{lccc}
\hline Öğrenme Stili & f & Ortalama & Ss \\
\hline Değiştiren & 45 & 4,110 & 0,606 \\
Yerleştiren & 27 & 3,961 & 0,748 \\
Ayriştıran & 27 & 4,027 & 0,815 \\
Özümseyen & 47 & 4,166 & 0,463 \\
Toplam/Ortalama & $\mathbf{1 4 6}$ & $\mathbf{4 , 0 8 5}$ & $\mathbf{0 , 6 3 7}$ \\
\hline
\end{tabular}

Özümseyen ve değiştiren öğrenme stiline sahip öğretmen adaylarının yerleştiren ve ayrıştıran öğrenme stiline sahip öğretmen adaylarına göre MTÖ puan ortalamaları daha yüksektir. Bu sonucun anlamlı olup olmadığını tespit etmek için tek yönlü ANOVA testi yapılmış ve sonuçlar Tablo 13'de sunulmuştur.

Tablo 13. Öğrenme stillerine göre MTÖ puanlarına ilişkin ANOVA testi sonuçları

\begin{tabular}{lccccc}
\hline & $\begin{array}{c}\text { Kareler } \\
\text { Toplami }\end{array}$ & Df & Ortalama Kare & f & Anlamlılık \\
\hline Gruplar Aras1 &, 839 & 3 & 0,280 & & 0,562 \\
Grup İçi & 57,857 & 142 & 0,407 & 0,686 & \\
Toplam & $\mathbf{5 8 , 6 9 6}$ & $\mathbf{1 4 5}$ & & &
\end{tabular}

Tablo 13'teki öğretmen adaylarının öğrenme stillerine göre MTÖ puanlarına ilişkin yapılan tek yönlü ANOVA testi sonuçlarına göre aradaki farkın anlamlı olmadığı bulunmuştur. ( $p=0,562 ; p>0,05)$. 


\section{TARTIŞMA ve SONUÇ}

$\mathrm{Bu}$ araştırma ilköğretim matematik öğretmen adaylarının öğrenme stillerini akademik başarıları ve matematiğe yönelik tutumları açısından incelemek amacıyla gerçekleştirilmiştir. Araştırmanın bu bölümünde elde edilen bulgular yardımıyla ulaşılan sonuçlar, tartışma ve sonuçlara yönelik önerilere yer verilmiştir.

İlköğretim matematik öğretmen adayları özümseyen ve değiştiren öğrenme stillerine yerleştiren ve ayrıştıran öğrenme stillerine göre daha fazla sahiptirler. KÖSE kullanılarak yapılan diğger çalışmalar incelendiğinde bu araştırmada bulunan sonuçlara benzerlik gösterecek şekilde bulgulara ulaşan çalışmalarla birlikte farklı bulgulara ulaşan çalışmalar da bulunmaktadır. Örneğin, Çelik, Yalçın, Çatal \& Aydın (2014) eğitim fakültesi öğrencilerinin öğrenme stillerini bazı değişkenler açısından inceledikleri çalışmalarında ilköğretim matematik öğretmen adaylarının bu araştırmaya benzer şekilde baskın olarak özümseyen ve değiştiren öğrenme stillerine sahip olduklarını ortaya koymuştur. Bir diğer çalışmada Zengin \& Alşahan (2011) ilköğretim öğretmen adaylarının öğrenme stilleri incelemiş, ilköğretim matematik öğretmen adaylarının baskın olarak ayrıştıran ve özümseyen öğrenme stillerine sahip oldukları bulgusuna ulaşmışlardır. Bahar, Özen \& Gülaçtı (2009) ise ilköğretim matematik öğretmen adaylarının daha çok ayrıştıran ve yerleştiren öğrenme stiline sahip oldukları sonucuna ulaşmıştır. Farklı çalışmalarda farklı sonuçlara ulaşılmasında, çalışma gruplarının sosyo-kültürel özelliklerinin farklı olmasının etkili olduğu düşünülmektedir. Diğger yandan eğitim ortamlarının fiziksel özellikleri, öğretim üyelerinin uyguladı̆̆ı yöntem ve teknikler gibi bazı etmenler de bu farklılaşmaya yol açmı̧ olabilir.

Öğretmen adaylarının öğrenme stillerinin cinsiyete göre anlamlı farklılık göstermediği görülmüştür. Bayan öğretmen adayları baskın olarak değiştiren ve özümseyen öğrenme stiline eşit oranda sahipken, erkek öğretmen adayları ise baskın olarak özümseyen öğrenme stiline sahiptirler. Öğrenme stillerini cinsiyete göre inceleyen benzer çalışmalar incelendiğinde bu araştırmanın sonuçlarını destekleyen bulgulara rastlanmıstır (Bahar, Özen \& Gülaçtı, 2009; Çelik, Yalçın, Çatal \& Aydın, 2009; Küçükkaragöz, Deniş, Ersoy \& Karataş, 2009; Okur, Bahar, Akgün \& Bekdemir, 2011). Bu sonuçlardan hareketle cinsiyetin öğretmen adaylarının öğrenme stili tercihleri üzerinde etkili olmadığı söylenebilir.

Normal öğretimde öğrenim gören öğretmen adaylarının baskın olarak değiştiren, ikinci öğretimde öğrenim gören öğretmen adaylarının ise baskın olarak özümseyen öğrenme stiline sahip oldukları ancak yapılan ki-kare testi sonuçlarına göre bu farkın anlamlı olmadığı bulunmuştur. Literatürde ilköğretim matematik öğretmen adaylarının öğrenme stillerini öğretim türüne göre inceleyen tek bir çalışmaya rastlanmıştır. Zengin \& Alşahan'ın (2011) bulgularına göre öğretim türüne göre baskın öğrenme stili değişmemektedir ancak bu verinin istatistiksel olarak anlamlı olup olmadığı incelenmemiş, veriler sadece frekans tablosunda gösterilmiştir. Öte yandan öğrenme stilleri ile öğretim türü arasında istatistiksel açıdan anlamlı bir fark olmadığı bulgusu, farklı branşlardaki öğretmen adaylarıyla yapılan çalışmalarda ulaşılan sonuçlar ile de benzerlik göstermektedir. Can (2011), sınıf öğretmeni adaylarının öğrenme stilleri ile bazı değişkenler arasındaki ilişkiyi araştırdığ1 çalışmasında normal öğretim ile ikinci öğretim öğrencilerinin en fazla özümseyen öğrenme stiline sahip olduklarını ancak öğrenme stilleri ile öğretim türü arasında anlamlı bir ilişki olmadığı sonucuna ulaşmıştır. Çaycı \& Ünal (2006) ise "Sınıf Öğretmeni Adaylarının Sahip Oldukları Öğrenme Stillerinin Çeşitli Değişkenlere Göre İncelenmesi” adlı araştırmalarında öğretmen adaylarının öğrenim gördükleri öğretim türünün baskın öğrenme stillerine göre farklılaşmadığı sonucuna ulaşmıştır. Buradan öğretim türünün öğrenme stili tercihlerinde bir farklılık oluşturmadı̆̆ı söylenebilir.

Değiştiren ve Özümseyen öğrenme stiline sahip öğretmen adaylarının yerleştiren ve ayrıştıran öğrenme stiline sahip öğretmen adaylarına göre akademik başarıları daha yüksek olmakla birlikte bu sonucun istatistiksel olarak anlamlı olmadığı görülmüştür. Peker (2005), “İlköğretim Matematik Öğretmenliğini Kazanan Öğrencilerin Öğrenme Stilleri ve Matematik Başarısı Arasındaki İlişki” başlıklı araştırmasında üçüncü tip öğrenenler ile dördüncü tip öğrenenlerin matematik başarıları arasında üçüncü tip öğrenenler lehine anlamlı farklılık tespit etmiştir. Okur, Bahar, Akgün \& Bekdemir (2011) ise ayrıştıran öğrenciler ile değiştiren ve 
yerleştiren öğrenciler arasında akademik başarı açısından anlamlı farklılık olduğu sonucuna ulaşmışır. Ancak Peker (2005)'in örneklemini bu araştırmadan farklı olarak yalnızca 1. sınıf öğrencileri oluşturmuş ve akademik başarı kriteri olarak da yine bu araştırmadan farklı olarak not ortalamaları yerine 2004 ÖSS başarıları ölçüt olarak ele alınmıştır. Ayrıca Peker (2005), araştırmasında Kolb Öğrenme Stilleri yerine 4MAT Öğrenme Stilleri modelini kullanmıştır. Okur, Bahar, Akgün \& Bekdemir (2011) ise örnekleme 163 ilköğretim matematik öğretmen adayının yanı sıra iki farklı üniversiteden toplam 289 matematik bölümü öğrencisini de dâhil etmiştir. Bulgulardaki farklılıkların bu nedenlerden kaynaklanabileceği düşünülmektedir.

İlköğretim Matematik öğretmen adayları MTÖ'den "Katıliyorum" seçeneğini tercih etmişlerdir. Bu öğretmen adaylarının matematiğe yönelik tutumlarının yüksek düzeyde olduğunun göstergesidir. Özümseyen ve değiştiren öğrenme stiline sahip öğretmen adaylarının yerleştiren ve ayrıştıran öğrenme stiline sahip öğretmen adaylarına göre MTÖ puan ortalamaları daha yüksektir. Ancak bu sonucun istatistiksel olarak anlamlı olmadığı görülmüş̧ür. Bu öğretmen adaylarının matematiğe yönelik tutumlarının, öğrenme stillerine göre değişmediğini göstermektedir. Literatür incelendiğinde ilköğretim matematik öğretmen adayların matematiğe yönelik tutumlarını öğrenme stilleri açısından inceleyen herhangi bir çalışmaya rastlanılmadığından bu bulgu farklı çalışmalardaki bulgular ile karşılaştırılamamıştır.

Araştırmanın sonuçlarına yönelik olarak aşağıdaki önerilere yer verilmiştir;

Öğretmen adayları baskın olarak özümseyen ve değiştiren öğrenme stillerine sahiptir. Kolb \& Kolb’un (2005) belirttiğine göre özümseyen öğrenme stiline sahip bireyler insanlara daha az odaklanıp, fikirler ve soyut kavramlarla daha fazla ilgilenirken; değiştiren öğrenme stiline sahip bireylerin ise kültürel ilgileri yoğundur ve bu bireyler fikir üretiminin gerektiği durumlarda daha iyi performans sergilerler. Bu nedenle, öğretim elemanları öğretim sürecini tasarlarken öğretmen adaylarının bu özelliklerini dikkate almalıdır. Bununla birlikte diğer iki öğrenme stiline sahip öğretmen adayları da bulunmaktadır. Öğretim sürecinde öğretim elemanlarının her sinıfta farklı ögrenme stiline sahip öğrencilerin olduğunu göz ardı etmeyerek farklı öğrenme ortamları oluşturmasının öğrenme stili bakımından heterojen olan sınıflarda öğrenmeyi kolaylaştıracağı düşünülmektedir. Bu araştırmadaki bulguların farklı sınıf düzeyindeki veya bölümlerdeki öğretmen adaylarıly benzerlik gösterip göstermediği karşılaştırılmalı olarak incelenebilir. Ayrıca öğretmenlerin kendi öğrenme stillerini öğrencilerine yansıtıp yansıtmadığına ilişkin araştırmalar yapılabilir.

\section{KAYNAKÇA}

Açık, E. (2013). Lise ögrencilerinin öğrenme stilleri ve problem çözme becerileri arasindaki ilişkinin incelenmesi. (Yayımlanmamış yüksek lisans tezi). YÖK Ulusal Tez Merkezi veri tabanından elde edildi. (Tez no: 336332)

Aktaş, İ. P. \& Mirzeoğlu, D. E. (2009). İlköğretim II. Kademe Öğrencilerinin Öğrenme Stillerinin Okul Başarılarına ve Beden Eğitimi Dersine Yönelik Tutumlarına Etkisi. SPORMETRE Beden Eğitim ve Spor Bilimleri Dergisi, 7(1), 1-8.

Alkan, H., Güzel, E. \& Elçi, A. (2004). Öğrencilerin Matematiğe Yönelik Tutumlarında Matematik Öğretmenlerinin Üstlendiği Rollerin Belirlenmesi. XIII. Ulusal Ë̆gitim Bilimleri Kurultayı.

Bahar, H. H., Özen, Y. \& Gülaçtı, F. (2009). Eğitim Fakültesi Öğrencilerinin Cinsiyet ve Branşa Göre Akademik Başarı Durumları ile Öğrenme Stillerinin İncelenmesi. Ankara Üniversitesi Eğgitim Bilimleri Fakültesi Dergisi, 42(1), 69-86.

Can, Ş. (2011). Sınıf Öğretmeni Adaylarının Öğrenme Stilleri ile Bazı Değişkenler Arasındaki İlişkinin İncelenmesi. Hacettepe Üniversitesi Ë̈itim Fakültesi Dergisi, 41, 70-82.

Çelik, H. C. \& Bindak, R. (2005). Sınıf Öğretmenliği Bölümü Öğrencilerinin Matematiğe Yönelik, Tutumlarının Çeşitli Değişkenlere Göre İncelenmesi. Kastamonu Eğitim Dergisi, Cilt: 13, Sayı: 2, 427-436.

Çakır, R. \& Akbaş, O. (2013). Lise Öğrencilerinin Öğrenme Stillerinin Bazı Değişkenlere Göre İncelenmesi. Mehmet Akif Ersoy Üniversitesi Eğitim Fakültesi Dergisi, 13, (25), 138-159.

Çayc1, B., \& Ünal, E. (2007). Sınıf Öğretmeni Adaylarının Sahip Oldukları Öğrenme Stillerinin Çeşitli Değişkenlere Göre İncelenmesi. Bilim, Eğitim ve Düs̈̈̈nce Dergisi, 7(3), 1-16.

Çelik, F., Yalçın, R., Çatal, Ö. G. \& Aydın, A. (2014). Öğretmen Adaylarının Öğrenme Stillerinin Bazı Değişkenler Açısından İncelenmesi. Mehmet Akif Ersoy Üniversitesi Eğitim Fakültesi Dergisi, 1(32), 114,129. 
Erol, B. (2013). İlköğretim matematik ögretmenliği 2. sinf öğrencilerinin fiæị dersine yönelik tutumlar ile ögrenme stilleri arasindaki iliski. (Yayımlanmamıș yüksek lisans tezi). YÖK Ulusal Tez Merkezi veri tabanından elde edildi. (Tez no: 342347)

Felder, R. M. \& Silverman, L. K. (1988). Learning and Teaching Styles in Engineering Education. Engineering Education, 78(7), 674-681.

Gencel, İ. E. (2007). Kolb’un Deneyimsel Öğrenme Kuramına Dayalı Öğrenme Stilleri Envanteri-III'ü Türkçe'ye Uyarlama Çalısması. Dokuz. Eylül Üniversitesi Sosyal Bilimler Enstitüsü Dergisi, 9(2), 120-139.

Hein, T.L. \& Budny, D. D. (2000). Styles and Types in Science and Engineering Education. Paper Presented International Conference on Engineering and Computer Education, San Paulo, Brazil.

Karademir, E. \& Tezel, Ö. (2005). Sınıf Öğretmeni Adaylarının Öğrenme Stillerinin Demografik Değişkenler Açisindan Incelenmesi. Pamukkale Üniversitesi Ë̆itim Fakültesi Dergisi, 28, 129-145.

Keefe, J.W (1979). Learning Style: An overview. In NASSP's Student learning styles: Diagnosing and prescribing programs (pp. 1-17). Reston, VA: National Association of Secondary School.

Kolb, D. A. (1984). Experiential Learning: Experience as the Source of Learning and Development. New Jersey: Prentice Hall, Inc., Engle wood Cliffs.

Kolb, D. A. (1999). The Kolb Learning Style Inventory. Boston: Hay Resources Direct.

Kolb, A. Y. \& Kolb, D. A. (2005). The Kolb Learning Style Inventory 3.1: Technical Soecifications. Baston, MA: Hay Resources Direct.

Küçükkaragöz, H., Deniş, H., Ersoy, E. \& Karataş, E. (2009). İlköğretim Matematik, Fen Bilgisi ve Türkçe Öğretmen Adaylarının Öğrenme Stilleri ve Problem Çözme Becerilerinin İncelenmesi. In Canakkale, Turkey: The First International Congress of Educational Research.

Lemire, D. (1996). Using learning styles in education: research and problems. Journal of Accelerated Learning and Teacbing, 21(1-2), 45-59.

Okur, M., Bahar, H. H., Akgün, L. \& Bekdemir, M. (2011). Matematik Bölümü Öğrencilerinin Öğrenme Stilleri ile Sürekli Kayg1 ve Akademik Başarı Durumları. Türkiye Sosyal Arasstrmalar Dergisi, 153(153), 123134.

Önder, F. (2012). Issbirlikli gruplarda ögrenme stillerinin firik dersi basarısı ile hatırda tutma düreyine etkisinin incelenmesi. (Yayınlanmamıș doktora tezi). YÖK Ulusal Tez Merkezi veri tabanından elde edildi. (Tez no: 313083).

Peker, M. (2005). İlköğretim Matematik Öğretmenliğini Kazanan Öğrencilerin Öğrenme Stilleri ve Matematik Başarısı Arasındaki İlişki. Eğitim Araştırmalar, 21, 200-210.

Peker, M. ve Aydın, B. (2003). Anadolu ve Fen Lisesindeki Öğrencilerin Öğrenme Stilleri. Pamukkale Üniversitesi Ë̈itim Fakültesi Dergisi, 14, 167-172.

Şirin, A. \& Güzel, A. (2006). Üniversite Öğrencilerinin Öğrenme Stilleri ile Problem Çözme Becerileri Arasındaki İlişkinin İncelenmesi. Kuram ve Uygulamada Ë̈itim Bilimleri Dergisi, 6(1), 231-264.

Veznedaroğlu, R. L. \& Özgür, A. O. (2005). Öğrenme Stilleri: Tanımlamalar, Modeller ve İşlevleri. İlkögrretimonline, 4(2), 1-16. [Çevrim-içi: http://www.ilkogretim-online.org.tr], Erişim Tarihi: 21.01.2014.

Zengin, R. \& Alşahan, Ö. L. (2011). İlköğretim Öğretmen Adaylarının Öğrenme Stillerinin İncelenmesi. Errincan Eğitim Fakültesi Dergisi, 13(2), 143-153.

\section{Citation Information}

Çelik, H., Ç. \& Gündüz, S. (2016) İlköğretim Matematik Öğretmen Adaylarının Akademik Başarı ve Matematĭge Yönelik Tutumlarının Öğrenme Stilleri Açısından İncelenmesi. Dicle Üniversitesi Ziya Gökalp Eğitim Fakültesi Dergisi, 28, 278-288. 